\title{
Spotkania literackie na lekcji \\ - satysfakcje i porażki zawodowe nauczycieli
}

\section{Literary encounters in the lesson - professional satisfactions and failures of teachers}

\author{
|Zofia Zasacka
Bblioteka Narodowa
ORCID: 0000-0002-3437-5578
}

Abstract: The teacher plays a key role as a mediator in the school's literary communication between the literary text and the students. The success of Polish didactics, as Bożena Chrząstowska proved, depends on the quality of this mediation. The analyses contained in the article direct attention to the attitudes of Polish language teachers related to their didactic work, and especially to the relationship between the student and the teacher built on the joint reading of a literary text. The empirical material used analyzes the difficulties that teachers encounter in working with students and the satisfaction they derive from their profession. The article is based on the analysis of the results of a survey conducted among 104 teachers of the Polish language of the third grade of lower secondary schools from all over Poland as a fragment of the last edition of the national youth readership survey.

Key words: Polish language teacher, reader's literary response in the school context, youth readership, Polish literature didactics, teachers' job burnout

Streszczenie: Nauczyciel odgrywa kluczową rolę jako pośrednik w komunikacji literackiej szkoły między dziełem literackim a uczniami. Sukces polskiej dydaktyki, jak udowodniła Bożena Chrząstowska, zależy od jakości tej mediacji. Analizy zawarte w artykule kierują uwagę na postawy lektorów języka polskiego związane z ich pracą dydaktyczną, a zwłaszcza na relację między uczniem a nauczycielem zbudowaną na wspólnym czytaniu utworu literackiego. Wykorzystany materiał empiryczny analizuje trudności, jakie nauczyciele napotykają $\mathrm{w}$ pracy $\mathrm{z}$ uczniami, oraz satysfakcję, jaką czerpią $\mathrm{z}$ wykonywanego zawodu. W artykule wykorzystano analizę wyników ankiety przeprowadzonej wśród 104 nauczycieli języka polskiego klas trzecich gimnazjów z całej Polski jako fragment ostatniej edycji ogólnopolskiego badania czytelnictwa młodzieży.

Słowa kluczowe: nauczyciel języka polskiego, recepcja literatury w szkole, czytelnictwo młodzieży, dydaktyka polska, wypalenie zawodowe nauczycieli

Bożena Chrząstowska w swojej pracy naukowej śledziła doświadczenia lekturowe uczniów i odbiór literatury pięknej czytanej w szkole w określonych celach edukacyjno-wychowawczych. Ramy szkolne determinują 
przebieg komunikacji literackiej. Nauczyciel kierujący szkolnym czytaniem uczniów jako pośrednik na osi dzieło literackie - czytelnik (Chrząstowska 1978) jest ograniczany w swoich zabiegach wymogami instytucji oświatowej. Chrząstowska podsumowuje wyniki prowadzonych badań:

im mniej ubezwłasnowolniony nauczyciel w układzie nadawczym, im częściej kieruje się indywidualnymi rozwiązaniami, niezależnie od zwyczajów przyjętych w praktyce, tym bardziej prawidłowy i efektywny jest przebieg procesu dydaktycznego (Chrząstowska 1977, 177).

O sukcesach w pracy dydaktycznej decyduje to, na ile polonista potrafi wnosić do ograniczeń programowych i formalnych instrukcji indywidualny wkład, wykorzystać swoje doświadczenia literackie czy współczesną myśl literaturoznawczą (Chrząstowska 1977). Badania Chrząstowskiej dążyły do obserwacji procesu dydaktycznego ze społeczno-kulturowej perspektywy, a szkolny odbiór był śledzony w kontekście społecznych funkcji komunikatów literackich. Takie spojrzenie na komunikację literacką bliskie jest koncepcji badawczej przyjętej przez socjologiczne badania czytelnictwa młodzieży prowadzone w Bibliotece Narodowej. Przynoszą one analizy młodzieżowych sposobów czytania: wyborów wartościujących i oczekiwań czytelniczych, form uczestnictwa w społecznym obiegu książki i ich społeczno-demograficzne uwarunkowania (Zasacka 2020).

Tematem artykułu są rezultaty analiz fragmentu ogólnopolskiego badania czytelnictwa młodzieży szkolnej, poświęconego pracy dydaktycznej nauczycieli języka polskiego danych uczniów (Zasacka 2020; 2021). Prezentowane analizy kierują uwage na postawy polonistów szkolnych związane z obowiązkami zawodowymi oraz na źródła satysfakcji i porażek w wykonywanej profesji, a zwłaszcza na relacje między uczniem a nauczycielem budowane na wspólnym czytaniu utworu literackiego. Proponuję spojrzenie na lekcje języka polskiego z subiektywnej perspektywy nauczycieli i ich oczekiwań wobec istoty ich pracy, jaką jest komunikacja z wychowankami. Warunkiem skutecznej dydaktyki literatury, idąc za myślą Chrząstowskiej, jest przekształcenie rzeczywistych potrzeb czytelniczych młodzieży w zainteresowania estetyczne i świadome wybory wartościujące (Chrząstowska 1977). Aby taki proces zaistniał, nauczyciel polonista powinien nawiązać z grupą młodzieży w klasie szkolnej relacje, które pozwolą lepiej poznać ich zainteresowania, w tym pozaszkolne doświadczenia czytelnicze (Zasacka 2021).

Wykorzystany w artykule materiał empiryczny posiada wartość historyczną, gimnazjów nie ma - jednak nauczycielki i nauczyciele pozostali, a cele i zadania, które stoją przed ich pracą dydaktyczną, są podobne. Chciałabym zwrócić uwagę na te aspekty pracy nauczycieli polonistów, które mogą być aktualne niezależnie od reform systemu edukacji i przekraczają wąskie konteksty „tu i teraz”. Istotą podjętych analiz postaw nauczycielskich jest nastawienie i sposoby określania celów w pracy z młodzieżą, 
które wychodzą poza realizację podstawy programowej, a skupiają się na uczniowskim rozwoju i zaangażowaniu czytelniczym. Szkoła to miejsce codziennych spotkań. Praca nauczyciela, poza czasem zdalnego nauczania, w dużej części polega na bezpośrednich relacjach z uczniami i ich rodzicami oraz innymi nauczycielami. O jakości tych relacji społecznych mówi klimat szkoły (Kulesza, Kulesza 2015), który też wpływa na satysfakcję zawodową nauczyciela (Maslach, Leiter 2011). Deficyty w kontroli nad relacjami z uczniami, ich depersonalizacja, brak wzajemności, sympatii i podmiotowości stanowić mogą oznakę wypalenia zawodowego nauczycieli i współwystępującej z nim niskiej efektywności pracy dydaktycznej i wychowawczej (Maslach, Leiter 2008; Maslach, Leiter 2011).

W artykule zostały wykorzystane analizy części wyników czwartej edycji ogólnopolskiego badania czytelnictwa młodzieży przeprowadzonej w listopadzie 2017 roku $^{1}$, która dotyczy nauczycieli języka polskiego badanych uczniów (Zasacka 2021). Zostają tu przedstawione rezultaty ankiety śledzącej stosunek polonistów i polonistek do pracy zawodowej, trudności, jakie napotykają w pracy z uczniami i jak sobie z nimi radzą oraz jakiego typu satysfakcje daje im praca w szkole, jak budują relacje z uczniami.

Badanie realizowano na ogólnopolskiej reprezentacji uczniów trzeciej klasy gimnazjum, otrzymane wyniki możemy uogólnić i odnieść do całej populacji młodzieży w tym wieku. Do uczniów docierano przez szkoły, do których uczęszczali² ${ }^{2}$ Badanie zostało przeprowadzone w listopadzie 2017 roku w 104 szkołach, ankiety wypełniło m.in. 1794 uczniów, 104 nauczycieli języka polskiego uczących w wylosowanych klasach (Zasacka 2020, 18-24). Jeśli próba uczniów spełnia warunki ogólnopolskiej, losowej, reprezentatywnej pod względem demograficznym (płeć, wiek, miejsce lokalizacji szkoły), to nauczyciele, którzy uczyli języka polskiego w klasach partycypujących $\mathrm{w}$ tymże badaniu, nie zostali dobierani tak, aby spełniać warunki reprezentacji wszystkich nauczycieli uczących w takich szkołach. Natomiast materiał empiryczny uzyskany dzięki odpowiedziom nauczycieli na specjalnie dla nich przeznaczone pytania kwestionariusza stanowi unikalne źródło danych o opiniach i postawach polonistów uczących w ówczesnych gimnazjach ulokowanych na terenie całej Polski.

W badaniu uczestniczyły 104 osoby, należy podkreślić, że były to przede wszystkim kobiety (102), a tylko 2 mężczyzn (Zasacka 2021). Polonistki i poloniści mają ukończone wyższe studia: $88 \%$ filologię polską, $11 \%$ edukację wczesnoszkolną, $4 \%$ pedagogikę, $31 \% \mathrm{z}$ nich studiowało jeszcze inne kierunki. Jest wśród nich 70\% nauczycielek i nauczycieli dyplomowanych, $21 \%$ mianowanych, $6 \%$ kontraktowych i tylko jedna stażystka. Co druga uczestnicząca w badaniu osoba pracowała w wiejskiej szkole.

\footnotetext{
${ }^{1}$ Badanie zrealizowane $\mathrm{w}$ ostatnim roczniku funkcjonowania trzeciej klasy gimnazjum - w tym czasie we wrześniu 2017 została wdrożona reforma oświaty wprowadzająca nową podstawę programową i likwidująca gimnazja i wydłużająca o dwa lata szkołę podstawową.

2 Realizacja badania była przeprowadzona w Bibliotece Narodowej i finansowana z dotacji celowej Ministerstwa Kultury i Dziedzictwa Narodowego, zrealizowana w terenie przez CBOS.
} 
Badani nauczyciele są przekonani, że ich profesja polega nie tylko na zarabianiu pieniędzy, nie chcieliby zmienić miejsca pracy ani zawodu i chwalą sobie szkołę, w której są zatrudnieni (wykres 1). Wszyscy zadeklarowali, że odczuwają w większym lub mniejszym stopniu satysfakcję z efektów swojej pracy w szkole. Jednak mają poważne wątpliwości, czy ich wysiłki są doceniane przez innych ludzi. Wynik ten może świadczyć o pozytywnej motywacji i zaangażowaniu w zawód, który często nie ma społecznego wsparcia i prestiżu. Taka sytuacja może stanowić źródło stresu i braku zawodowego spełnienia (Kocór 2019). Przyjrzyjmy się bliżej temu, jakich satysfakcji dostarcza polonistkom i polonistom praca z uczniami.

Wykres 1: Rozkład procentowy odpowiedzi dotyczących stosunku nauczycieli do ich pracy zawodowej $\mathrm{N}=100 \%=104$

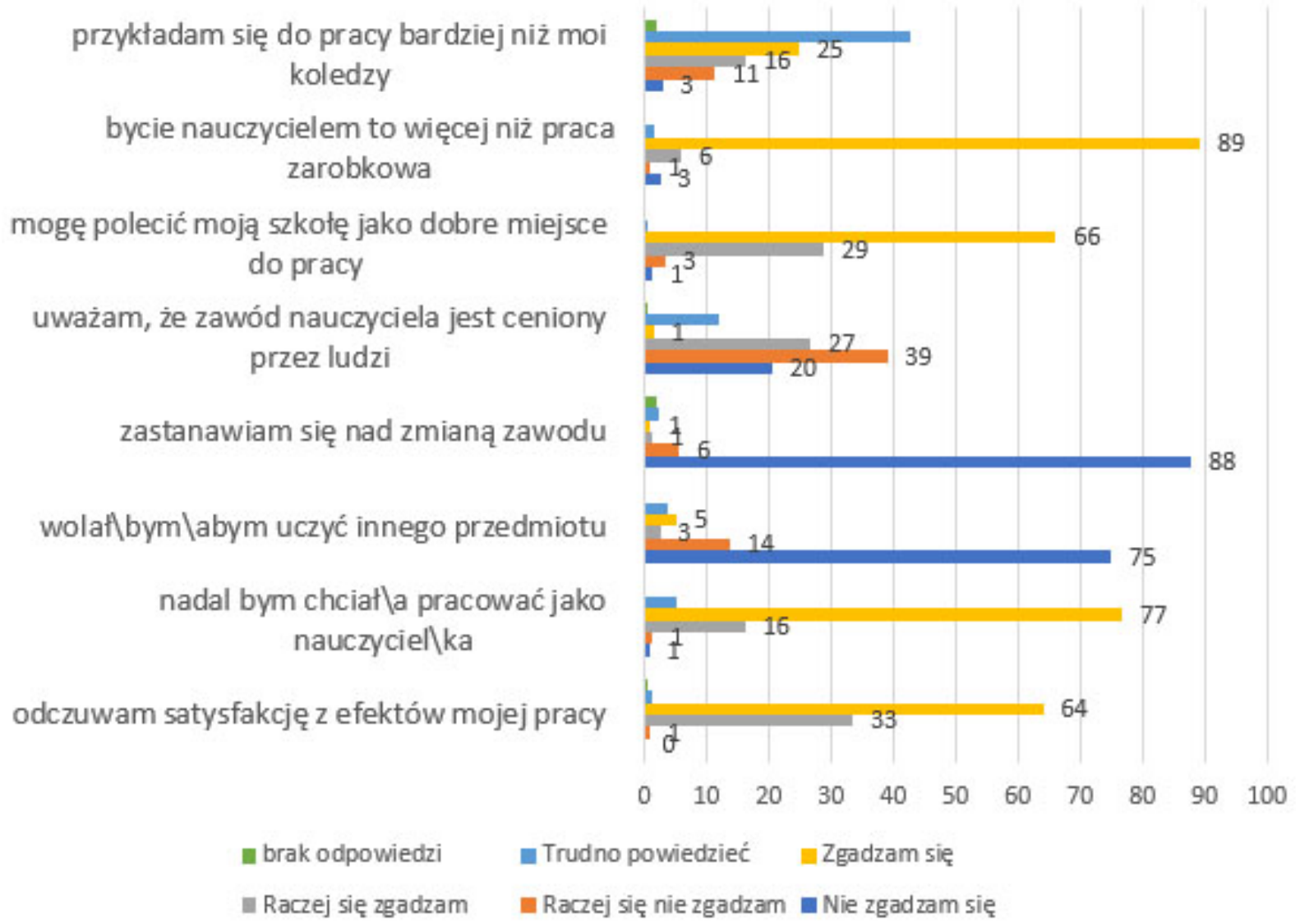

Źródło: BN, opracowanie własne

\section{Satysfakcje z pracy na lekcjach polskiego: uczniowskie zaanga- żowanie, postępy edukacyjne, rozwój intelektualny podopiecznych, dobre relacje}

Poloniści szkolni, którzy zadeklarowali, że odnajdują satysfakcję w pracy z uczniami (stanowili $69 \%$ badanych), opowiadali ${ }^{3}$ o tym, co potrafi ich zainspirować w pracy w szkole, co motywuje pozytywnie, niesie satysfakcję i nadaje sens codziennym wysiłkom. 
Spotkania literackie na lekcji - satysfakcje i porażki zawodowe nauczycieli

\subsection{Uczniowie zaangażowani na lekcjach, motywowani, chętni do pracy}

Analiza treści odpowiedzi nauczycieli odnajdujących satysfakcję w pracy dowiodła, że bardzo ważne są konkretne sukcesy edukacyjne podopiecznych, na które wskazywał co piąty polonista odczuwający satysfakcję z pracy z uczniami. Jednak największe zadowolenie przynosi nauczycielom praca dydaktyczna z uczniami, którzy potrafią się zaangażować w lekcję (por tabela 1). Owo zaangażowanie oznacza według ich opinii to, że uczniowie są zmotywowani i chętni do nauki, wspólnej pracy.

Tabela 1: Źródła nauczycielskiej satysfakcji z pracy z uczniami ${ }^{4}$

\begin{tabular}{|l|l|}
\hline & OGÓŁEM \\
\hline $\begin{array}{l}\text { Zaangażowanie uczniów na lekcjach, w naukę, uczniowie } \\
\text { zmotywowani, chętni do pracy }\end{array}$ & $\%$ \\
\hline Dobre relacje z uczniami & 38 \\
\hline Postawy uczniów (odwaga, empatia) & 32 \\
\hline Obserwacja rozwoju uczniów, ich postępy w dorastaniu & 23 \\
\hline Sukcesy edukacyjne, dobre stopnie, nagrody w konkursach & 22 \\
\hline $\begin{array}{l}\text { Możliwość organizacji przedstawień teatralnych, ciekawych } \\
\text { projektów }\end{array}$ & 18 \\
\hline Przyrost umiejętności polonistycznych u uczniów & 10 \\
\hline Ogólne określenia & 9 \\
\hline $\begin{array}{l}\text { Świadomość, że przekazana wiedza pomoże im w przyszłości, } \\
\text { znaczenie lekcji języka polskiego }\end{array}$ & 6 \\
\hline Brak danych & 3 \\
\hline Ogółem \% & - \\
\hline Liczba osób (N) & 100 \\
\hline
\end{tabular}

Źródło: BN, opracowanie własne

Taka postawa przejawia się w pierwszym rzędzie w uczniowskiej systematyczności, pilności w realizowaniu szkolnych zadań. Oto przykładowe odpowiedzi uczących:

Praca uczniów na poziomie ich możliwości. Rzetelność i systematyczność w wykonywaniu zadań. Zaangażowanie w rozmaite przedsięwzięcia edukacyjne (47).

Czasami odczuwam satysfakcję, zwłaszcza wtedy, kiedy uczniowie są przygotowani do zajęć i chętnie wykonują zadania (74).

Większość uczących, ceniąc sobie zaangażowanie uczniów, wskazywała, że zaciekawienie omawianymi tematami przyczynia się do sukcesu dydaktycznego. Jest też źródłem nauczycielskiej satysfakcji z pracy zawodowej. Zainteresowanie literaturą, omawianymi tematami prowokuje kreatywność, aktywność na lekcji np. podejmowanie dyskusji, nawet wykraczającej 
poza temat lekcji; współpracę przy nowych formach pracy, projektach. Cytowane poniżej odpowiedzi pokazują, że zmotywowani do nauki uczniowie potrafią być $\mathrm{w}$ różny sposób zaangażowani w szkolne zadania. Oto typowa odpowiedź:

Wielu uczniów to osoby ambitne, czytające teksty, można z nimi realizować tematy kreatywnie, stosując niekonwencjonalne metody (67).

Są klasy szczególnie aktywne i zainteresowane omawianymi tematami, w których udaje się inspirować uczniów do dodatkowych zadań, dyskusji, konkursów itp. Oto przykładowe sytuacje:

Uczniowie zespołu klasowego na lekcji chętnie pracują metodami aktywizującymi. W ten sposób przyswajają i utrwalają wiadomości i umiejętności przeznaczone do realizacji w tej klasie (93).

Uczniowie chętnie współpracują na lekcji, wykazują zainteresowanie treściami omawianymi na lekcji, biorą udział w konkursach (48).

Czasami jednak wyzwaniem jest zaledwie plan minimum: czytanie lektur obowiązkowych - co dla niektórych pedagogów już staje się sukcesem:

Chyba jest to fakt, że zmobilizowałam ich do czytania lektur szkolnych, choć mam świadomość, że większość z nich robi to raczej niechętnie, czyli z konieczności (57).

W opiniach polonistów szkolnych satysfakcji czerpanej z obowiązkowości i zaangażowania uczniów na lekcjach języka polskiego towarzyszą cztery efekty: pierwszy to wzrost umiejętności polonistycznych, drugi dobre wyniki na egzaminach, trzeci to wykraczająca poza obowiązki chęć wykazania się - uczestnictwo uczniów w konkursach, last but not least, to dobre relacje z uczniami, oto znamienna odpowiedź nauczycielki, łącząca różne wątki:

Uczniowie angażują się podczas lekcji, obserwuję też postępy uczniów, cieszę się z ich sukcesów (87).

\subsection{Przyrost umiejętności polonistycznych, dobre wyniki na egza- minach, udział w konkursach przedmiotowych}

Część (tabela 1) nauczycieli dostrzega efekty swojej pracy i wyróżnia satysfakcję czerpaną z obserwacji przyrostu umiejętności polonistycznych u swoich podopiecznych, odczuwa radość z ich sukcesów i opanowania konkretnych kompetencji: uczniowie posiadają coraz bogatszy zasób słownictwa, interesują się literaturą, historią, chętnie czytają, widoczna jest coraz większa dojrzałość ich wypowiedzi, chęć do rozwijania czytelniczych, artystycznych pasji. Efektem owych postępów są wymierne sukcesy edukacyjne: dobre oceny i wyniki na egzaminach, olimpiadach, w różnych konkursach. Oto przykładowe odpowiedzi: 
Uczniowie są zdyscyplinowani, bliskie są im tematy patriotyczne. Udaje mi się rozwijać pasje czytelnicze np. zainteresowanie literaturą romantyzmu. Uczniowie odnoszą sukcesy w olimpiadach (2 finalistki) (46).

Uczniowie tej klasy publikują swoje teksty w magazynie „Redakcja XX”. Uczestniczą w konkursach, spotkaniach poetyckich (64).

Uczniowie wypracowali dobry styl wypowiedzi pisemnych. Są aktywni na lekcjach, chętnie wypowiadają się, posiadają bogaty zasób słownictwa, interesują się literaturą, historią (31).

Nauczycieli szczególnie cieszą obserwowane postępy edukacyjne wśród uczniów napotykających trudności w nauce:

Dobra atmosfera na lekcjach, czasem sukcesy w postaci pozytywnych ocen u uczniów z trudnościami w nauce (80).

\subsection{Możliwość obserwowania zmian zachodzących w młodym czło- wieku (14)}

Nauczycielki i nauczyciele (22\% odczuwających satysfakcję z pracy) z zadowoleniem śledzą rozwój uczniów, nie tylko patrzą na niego z perspektywy postępów edukacyjnych, ale też obserwują intelektualne, poznawcze zmiany, są zafascynowani procesem dorastania nastolatków. Możliwość przyglądania się ich rozwojowi to ważna nagroda za codzienny wysiłek, świadcząca o więzi z uczniami, ale też o sensie pracy dydaktycznej. Oto typowe odpowiedzi:

Źródłem satysfakcji jest obserwowanie jak wzrastają w wiedzy i umiejętności moi uczniowie, jak stają się mądrymi ludźmi (30).

Możliwość rozmawiania o literaturze i wprowadzania w arkana sztuki. Obserwowanie młodych, którzy otwierają się na literaturę, osiągnięcia uczniów (61).

Świadomość, że można inspirować uczniów nowymi ideami, książkami itd. Możliwość przyglądania się ich rozwojowi. Okazja do ciekawych rozmów(16).

Jest jeszcze jeden szczególny przejaw satysfakcji czerpanej z obserwacji rozwoju młodych ludzi: przekonanie, że poznana literatura, przyswojone na lekcjach polskiego umiejętności będą im potrzebne w ich późniejszym życiu:

Odczuwam satysfakcję z pracy z uczniami, gdyż bardzo lubię tę pracę. Cieszę się, gdy widzę jej wymierne efekty, gdy czuję, że „analiza” postaw bohaterów literackich pomaga młodzieży żyć (33).

Taki efekt dydaktyki polonistycznej można odnieść do proponowanego przez Bożenę Chrząstowską pojęcia świadomości literackiej, którą tworzą wiedza oraz szereg kompetencji literackich i językowych, gust (narzędzia do oceny utworu literackiego i formowania preferencji czytelniczych poprzez wybory estetycznie wartościujące) pozwalające wykorzystać szkolną wiedzę w obecnym i przyszłym życiu ucznia i wspierające jego aktywne uczestnictwo w życiu kulturalnym (Chrząstowska 1979, 41-86). 


\subsection{Relacje z uczniami, otwartość, akceptacja, wzajemne zrozumie- nie (7)}

Nauczyciele czerpią satysfakcję nie tylko z obserwacji rozwoju podopiecznych, ale też widzą efekty własnego zaangażowania w relacje z nimi, codziennych spotkań na lekcjach polskiego. Ważne stają się interakcje, badane osoby cenią sobie "dobry kontakt”, „dobre relacje”," inspirujące, ciekawe rozmowy” „możliwość wymiany poglądów” „wzajemne zrozumienie" zaufanie i akceptację. Co trzeci nauczyciel podkreślił znaczenie stymulujących i empatycznych kontaktów z uczniami. Niektórzy z nich mają klasy szczególnie udane, w których wzajemna sympatia sprzyja motywacji do pracy. Z tych odpowiedzi wyłania się lekcja szkolna nie tylko jako czas realizacji obowiązku szkolnego i podstawy programowej, ale spotkania odbywającego się na zasadach wzajemności i zaufania, ale też kultury osobistej. Oto odpowiedzi wskazujące na ten aspekt nadający sens pracy dydaktycznej:

Atmosfera wzajemnego poszanowania, dyscyplina, kultura osobista (104).

Dobre relacje owocują właściwą atmosferą pracy, zaangażowaniem uczniów (91).

Sympatia, której doświadczam ze strony uczniów. Praca we wspaniałym gronie (69).

Na relacyjny aspekt pracy dydaktycznej zwracała uwagę także Bożena Chrząstowska. Podkreślała, że „świadomość literacką ucznia kształtuje nie tylko wiedza kanoniczna, nabywana w szkole; rozwijają ją (lub hamują) wszelkie konteksty komunikacyjne, co trzeba wziąć pod uwagę" (Chrząstowska 1977, 142).

\subsection{Postawy uczniów: odwaga w wyrażaniu własnych opinii, empa- tia, kreatywność, otwartość}

Źródłem satysfakcji zawodowej mogą być też postawy uczniowskie obserwowane przez nauczycieli. Lekcje polskiego i dyskusje szkolne potrafią ujawnić hierarchie wartości, światopogląd, inteligencję nastolatków. Co piąty badany polonista czerpiący satysfakcję z pracy pedagogicznej zwracał uwagę na uczniowską samodzielność, niezależność sądów ujawniane w czasie szkolnych dyskusji. Wówczas dla pedagogów inspirujące są „kontakty z inteligentnymi osobami, możliwość wymiany poglądów”. Nauczyciele cenią u uczniów gotowość podejmowania trudnych debat, odwagę w wyrażaniu własnych opinii, wrażliwość, kreatywność, świeżość spojrzenia, empatię, umiejętność wartościowania (na takie postawy wskazało $23 \%$ badanych odnajdujących satysfakcję w pracy z młodzieżą). Oto przykładowe opinie:

Wrażliwość, otwartość na bieżące tematy, świeżość spojrzenia, kreatywność, pełni empatii (41).

Odnajduję satysfakcję z pracy z uczniami tego oddziału, ponieważ są to otwarte i mądre dzieci (95). 
Spotkania literackie na lekcji - satysfakcje i porażki zawodowe nauczycieli

Bardzo wysoki poziom intelektualny i kulturalny uczniów, umiejętność współdziałania, dojrzałość i otwartość (75).

\section{Trudności w pracy na lekcjach polskiego}

Lekcje polskiego to nie tylko źródło satysfakcji, ale też przysparzają szereg problemów: 68\% badanych nauczycieli przyznało, że napotykają je w swojej pracy z uczniami. Wykres 2 ilustruje, jak badane osoby oceniły przedstawione $\mathrm{w}$ pytaniu kwestionariusza możliwe trudności w pracy z uczniami.

\subsection{Brak motywacji do nauki, ambicji, niskie poczucie obowiązku (81)}

Badani nauczyciele udzielali najpierw odpowiedzi na pytanie „otwarte”, w którym samodzielnie wymieniali napotykane trudności w szkole. Tabela 2 prezentuje wyniki analizy treści tych odpowiedzi, wskazując najistotniejsze przeszkody napotykane $\mathrm{w}$ pracy z uczniami konkretnego oddziału uczestniczącego $\mathrm{w}$ badaniu. $\mathrm{Z}$ analizy odpowiedzi wyłania się szczególny problem: zróżnicowanie w szkolnych postawach i kompetencjach uczniów w poszczególnych klasach (tabela 2).

Tabela 2: Rozkład procentowy odpowiedzi na pytanie ${ }^{5}$ : Jeśli napotyka Pani\Pan trudności i kłopoty w swojej pracy z uczniami, to które są najistotniejsze?

\begin{tabular}{|l|l|}
\hline & OGÓŁEM \\
\hline $\begin{array}{l}\text { Uczniowie nie wykazują się sumiennością (brak motywacji } \\
\text { do nauki) }\end{array}$ & $\%$ \\
\hline Uczniowie nie lubią czytać lektur & 58 \\
\hline $\begin{array}{l}\text { Deficyty w określonych umiejętnościach polonistycznych } \\
\text { uczniów, braki z wcześniejszych lat nauki }\end{array}$ & 31 \\
\hline Klasa jest słaba i zróżnicowana intelektualnie & 18 \\
\hline Trudności wychowawcze, brak dyscypliny, kultury osobistej & 16 \\
\hline $\begin{array}{l}\text { Brak wsparcia od rodziny; negatywny wpływ środowiska } \\
\text { społecznego }\end{array}$ & 16 \\
\hline Przyczyny zewnętrzne & 13 \\
\hline Przyczyny organizacyjne & 6 \\
\hline Brak danych & 2 \\
\hline Ogółem & - \\
\hline N (liczba badanych) & 100 \\
\hline
\end{tabular}

Źródło: BN, opracowanie własne

Nauczyciele dostrzegający przeszkody $\mathrm{w}$ pracy na lekcjach języka polskiego oceniali to, w jakim stopniu różnice $\mathrm{w}$ umiejętnościach między uczniami stają się utrudnieniem - 19\% badanych przyznało, że to bardzo istotny problem (wykres 2).

\footnotetext{
${ }^{5}$ Wyniki analizy treści odpowiedzi na pytanie otwarte.
} 
Nawet jeśli ambitni i zaangażowani uczniowie dostarczają satysfakcji pedagogom, to z kolei źródłem trudności i zmartwień jest bierność części uczniów, bez motywacji do nauki, pozbawionych aspiracji, czemu często towarzyszą braki w wiedzy i umiejętnościach.

Powszechny kłopot (58\% nauczycieli dostrzegających trudności, por. tabela 2), na który się uskarżano, to niechęć do nauki uczniów, brak sumienności, poczucia obowiązku i ambicji. Jest to problem, który od lat wybija się na plan pierwszy (Biedrzycki i in. 2015; Zasacka, Bordzoł 2014, 161-185). Oto typowa odpowiedź:

Uczniowie tworzący zespół posiadają niską samoocenę, nie wierzą w swoje możliwości. Pracują niesystematycznie, brak w nich poczucia obowiązku. Nie posiadają umiejętności logicznego myślenia (18).

Nauczyciele, wskazując na niechęć uczniów do nauki, jednocześnie martwili się, że przeszkodą w dalszych postępach są wcześniejsze deficyty w kompetencjach językowych, ubogie słownictwo, a także kłopoty z czytaniem ze zrozumieniem. Oto przykładowa wypowiedź:

Klasa jest bardzo zróżnicowana intelektualnie. Kilkoro dzieci, choć bardzo sympatycznych, ma duże trudności z rozumieniem tekstów literackich (2).

Wykres 2: Rozkład procentowy odpowiedzi na pytanie: W jakim stopniu nauczanie w tym oddziale jest utrudnione przez: $(100 \%=\mathrm{N}=70)$

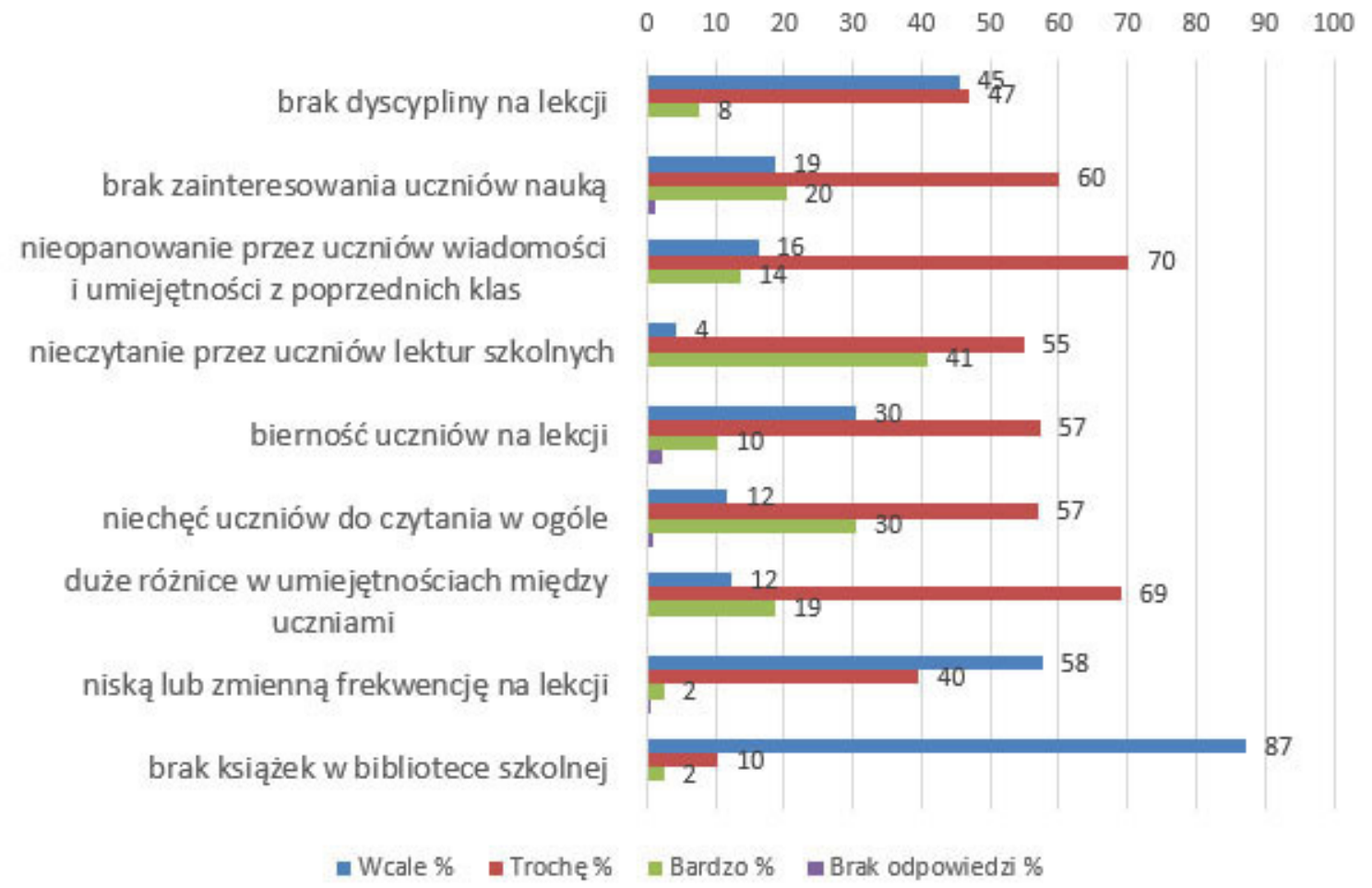

Źródło: BN, opracowanie własne

Niektórzy z badanych polonistów szkolnych wskazują wprost, że przyczyną niskiej uczniowskiej motywacji do nauki są trudności, których źródłem jest środowisko społeczne, niewystarczające wsparcie rodziców, braki w samokształceniu, a w efekcie widoczne są:

Polonistyka. Innowacje

Numer 14, 2021 
Spotkania literackie na lekcji - satysfakcje i porażki zawodowe nauczycieli

Niechęć do wysiłku umysłowego, ubogie słownictwo, brak kultury (39).

Problemy rodzinne, życiowe, które wpływają na całokształt (15).

Niski potencjał uczniów. Wpływ czynników środowiskowych na proces uczenia się. Brak wsparcia ze strony domu (48.)

Jedna z nauczycielek wskazała na przyczyny cywilizacyjne, zanurzenie w wirtualnym świecie:

Uczniowie często nie mają motywacji do zdobywania wiedzy i poszerzania swoich horyzontów. W przeważającej większości są uzależnieni od telefonów (gier), portali społecznościowych, nie potrafią nawiązywać interakcji i współpracować (68).

\subsection{Najistotniejszym problemem jest opór przed czytaniem lektur (93)}

Uczniowskiej niechęci do nauki i brakowi systematyczności towarzyszy, według badanych nauczycieli, brak zainteresowania lekturami szkolnymi. Ta kwestia to odwieczne zmartwienie polonistów (Zasacka, Bordzoł 2015; Janus-Sitarz 2015), którego nie złagodziła, a nawet może wzmocniła reforma oświaty likwidująca gimnazja (Błaszczyk 2020). Aż 41\% z 70 badanych nauczycieli skarżących się na trudności w pracy dydaktycznej uznało, że jednym z najważniejszych problemów jest nieczytanie przez uczniów lektur szkolnych (wykres 3). Kolejną przeszkodą (31\% badanych) jest brak motywacji do czytania literatury (tabela 2). Nauczyciele wymieniali też omijanie przez uczniów czytania oryginalnych tekstów literackich, wykorzystywanie streszczeń. Według oceny polonistów młodzież w ogóle coraz rzadziej czyta książki. Oto najbardziej typowe odpowiedzi:

Uczniowie niechętnie się uczą, nie chcą czytać lektur, ani obowiązkowych, ani nadobowiązkowych (104).

Niechęć uczniów do czytania. Nadmierne korzystanie z materiałów zamieszczonych w internecie (41).

Jedna z nauczycielek odnotowała:

Nie czytają lektur obowiązkowych, dużo łatwiej wyegzekwować przeczytanie lektur uzupełniających, zwłaszcza powieści młodzieżowych (101).

\subsection{Braki w kulturze osobistej uczniów i codziennej dyscyplinie}

Przyczyna, która psuje atmosferę na lekcji, to niska kultura osobista uczniów. Najczęściej towarzyszą jej słabe aspiracje edukacyjne, brak zainteresowania przedmiotem i dyscypliny w realizacji szkolnych obowiązków. Oto wybrane uwagi nauczycielskie, które sformułowało $16 \%$ badanych nauczycieli dostrzegających trudności w pracy dydaktycznej:

Brak zainteresowania i chęci do nauki, niekulturalne zachowania, skupienie na sporcie (102).

Brak dyscypliny, brak motywacji do pracy, niechęć, lenistwo, egoizm (87). 
Duża ilość uczniów ma trudności w nauce, objęci są pomocą PP, absencja na lekcjach (88).

Niektórzy uczniowie nie przygotowują się do zajęć, inni przeszkadzają w ich prowadzeniu (75).

Niektórzy uczniowie bardzo nieregularnie lub w ogóle nie realizują obowiązku szkolnego, a pomóc można tylko tym, którzy się w szkole pojawiają (14).

\section{Przełamywanie trudności}

W prezentowanym badaniu poloniści szkolni byli poproszeni o ocenę, w jakim stopniu są w stanie przezwyciężyć przeszkody napotykane w pracy dydaktycznej z młodzieżą. Wykres 3 podaje informacje o ich odpowiedziach.

Wykres 3: Rozkład procentowy odpowiedzi na pytanie: Jak często w swojej pracy na lekcjach języka polskiego w tej klasie udaje się Pani|Panu $(\mathrm{N}=70)$ :

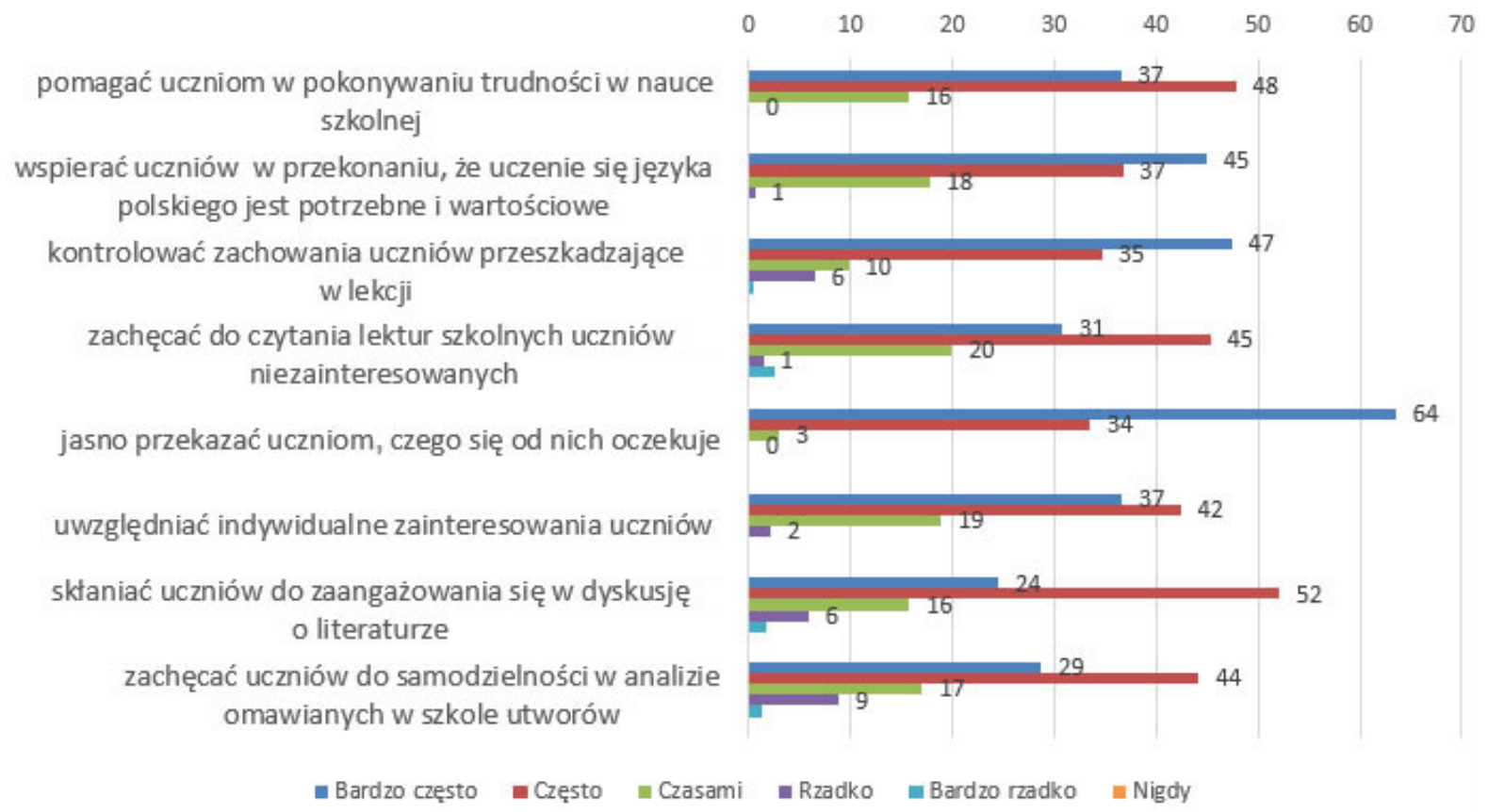

Źródło: BN, opracowanie własne

Kluczowymi kwestiami dla badanych, jak to zostało wcześniej przedstawione, obok niechęci do czytania literatury - zwłaszcza lektur szkolnych - jest niska motywacja do nauki oraz braki w kompetencjach komunikacyjnych i językowych części uczniów. Z deklaracji nauczycieli wynika, że w zdecydowanej większości starają się rozwiązać te problemy. Tylko nieliczne badane osoby przyznały się do przegranej, chociaż wcześniej $\mathrm{w}$ odpowiedziach na pytanie otwarte wymieniały szereg napotykanych przeszkód. Badani poloniści deklarują, że najlepiej sobie radzą w przekazywaniu i wyjaśnianiu uczniom swoich poleceń, kontroli dyscypliny na lekcjach oraz wspieraniu uczniów przy pokonywaniu trudności w nauce szkolnej. Jednak praca na lekcji z tekstem literackim wymaga najwięcej nauczycielskiego wysiłku. Najtrudniej jest zachęcić uczniów do samodzielności w analizie omawianych w szkole utworów - w efekcie co czwarta badana 
osoba przyznaje, że często ponosi porażkę. Niełatwo jest nauczycielom nakłonić podopiecznych do czytania lektur szkolnych - co piąty przyznał, że tylko „czasami” odnosi sukces. Bez czytania czy samodzielnej interpretacji dzieła literackiego (Chrząstowska 1979), a więc istoty odbioru literatury na lekcji szkolnej, mamy do czynienia z przegraną dydaktyki literackiej. Choć trudno jest przełamać uczniowską bierność przy omawianiu literatury, to jednak aż $3 / 4$ badanych przyznało, że uczniowie są często gotowi do dyskusji na lekcji. Również wielu uczniom brakuje pilności i motywacji do nauki - $18 \%$ badanych polonistów przyznaje, że tylko czasami udaje się ich przekonać, że warto uczyć się języka polskiego.

\section{Uwagi końcowe}

W postawach nauczycielek i nauczycieli języka polskiego wobec pracy dydaktycznej z uczniami rysują się dwie przeciwstawne tendencje. Pierwsza świadczy o tym, że większość badanych osób znajduje sens w pracy zawodowej, a jego źródłem jest przede wszystkim zaangażowanie uczniów w naukę i zainteresowanie literaturą. Codzienne spotkania na lekcjach polskiego z dorastającą młodzieżą i obserwacja zachodzących w niej zmian oraz doświadczanie własnego wpływu na ten rozwój jest dla wielu pedagogów źródłem satysfakcji. Świadomość, że wspólnie czytana literatura pomaga nastolatkom w dorastaniu i może być później przydatna w życiowych wyborach, motywuje polonistów do dydaktycznego trudu. Wsparciem emocjonalnym dla nauczycieli są udane relacje z podopiecznymi - wzajemne zrozumienie, objawy sympatii i uczniowskiej wdzięczności wzmacniają sens szkolnej codzienności. Poczucie bycia potrzebnym i pozytywne efekty wykonywanej pracy wydają się niezmiernie ważne dla nauczyciela.

Druga tendencja obejmuje reakcje na przeszkody w pracy z uczniami na lekcjach polskiego, wśród których - obok braku uczniowskiej motywacji do nauki - najbardziej uciążliwa jest trudna do przezwyciężenia niechęć do czytania literatury, a zwłaszcza lektur szkolnych. Jest to od lat obserwowane zjawisko (Bordzoł, Zasacka 2014), niesłabnące wśród polskich uczniów po reformie oświaty (Błaszczak 2019). Z owym oporem wobec czytania łączą się często niskie aspiracje edukacyjne, brak zainteresowania przedmiotem. W efekcie utrwala się zróżnicowanie kompetencji polonistycznych i aspiracji edukacyjnych w większości oddziałów. Inne, wcześniejsze badania empiryczne (Biedrzycki i in. 2015; Bordzol, Zasacka 2014; Janus-Sitarz 2015), poświęcone postawom zawodowym nauczycieli języka polskiego, konsekwentnie wskazują na nieczytanie lektur szkolnych jako przyczynę porażki dydaktycznej na lekcjach języka polskiego, oderwania od życia i pozbawionego sensu wyalienowanego nauczania (Gąsiorek, Zamorska 2019). Kontrasty w postawach czytelniczych uczniów ujawniają również wyniki badań czytelnictwa młodzieży (Zasacka 2020; 2019). 
Jeśli w danym oddziale przeważają uczniowie z brakiem motywacji do nauki i czytania, pojawia się niebezpieczeństwo zniechęcenia u nauczyciela i utraty przez niego wiary w sens pracy. Analizy wielowymiarowego zjawiska, jakim jest wypalenie zawodowe nauczycieli (Kocór 2010; 2019, Kirenko, Zubrzycka-Maciąg 2014, Jędryszek-Geisler, Izdebski 2019), wskazują na trzy jego aspekty - silną motywację do pracy, trudne warunki realizacji obowiązków zawodowych sprzyjające rozwojowi stresu i reakcje na stres, które łącznie budują proces utraty złudzeń, wzrastający pesymizm zawodowy i poczucie niemocy $w$ realizacji zawodowych zadań. Nauczyciele, mimo zaangażowania w pracę dydaktyczną i wychowawczą, wobec kumulujących się przeszkód w realizacji obowiązków i celów - jak podkreślają badacze problemu wypalenia zawodowego - mogą odczuwać niemoc, bezradność. Pozytywną motywację zastępują wówczas stres i rozczarowanie (Huget, Guzik 2014). Prezentowane badanie ukazuje nauczycielki i nauczycieli, którzy w większości są w stanie przezwyciężyć napotykane przeszkody, choć jedna z nich - uczniowska niechęć do czytania - stanowi poważne zagrożenie dla nauczycielskiego poczucia sensu wykonywanej pracy dydaktycznej. Trzeba być świadomym, że na motywacje i aspiracje uczniowskie ma wpływ nie tylko konkretny nauczyciel czy nawet cała instytucja i system oświatowy, ale też środowisko społeczno-kulturowe młodego człowieka, jego indywidualne predyspozycje, w tym także klimat szkoły, który budują przede wszystkim społeczne relacje (Kulesza, Kulesza 2015; Filipiak 2008; Kwiatkowski, Walczak 2017).

Nie ma najnowszych badań ogólnopolskich z okresu pracy zdalnej w czasie pandemii COVID-19, które by uwzględniały specyfikę pracy nauczycieli języka polskiego. Są jednak empiryczne świadectwa tego czasu i ukazują one, jak codzienne trudności nauczyciela wyostrzyły wcześniejsze słabości w funkcjonowaniu polskiego szkolnictwa, które budują m.in.: przeładowana podstawa programowa, ukryte nierówności, niedopasowanie metodyki kształcenia do potrzeb współczesnego świata oraz brak nowoczesnej infrastruktury cyfrowej (Czapliński i in. 2020, 19). Zdalna edukacja pogłębiła różnice między uczniami, zwłaszcza w ich motywacjach do nauki (Jankowiak, Jaskólska 2020, 6-8) oraz odsłoniła braki w kompetencjach cyfrowych nauczycieli (Buchner, Wierzbicka 2020, 37-80; Kania, Mucha-Iwaniczko, Szumal 2020). Ujawnił się także ważny dla sukcesu dydaktycznego kontekst społeczny - podmiotowo budowane relacje na lekcjach szkolnych. Podobne przesłanie ujawnia prezentowane badanie, kierujące uwagę na pozytywne relacje między nauczycielem i uczniami jako istotny składnik sukcesu dydaktycznego. Szkoła publiczna to miejsce spotkań dzieci z różnych środowisk społeczno-kulturowych, gdzie problem zróżnicowania kultury osobistej, aspiracji edukacyjnych i kompetencji uczniów jest nieuchronny. Nauczyciel powinien mieć wsparcie instytucjonalne w przezwyciężaniu tej bariery w pracy dydaktycznej. Wśród wniosków z raportów z badań edukacyjnych w czasie pandemii COVID-19 pojawiła się rekomendacja dotycząca

\section{Polonistyka. Innowacje}

Numer 14, 2021 
znaczenia relacji społecznych w szkole i zmiany modelu $\mathrm{z}$ transmisyjnego na relacyjny (Pyżalski, Poleszak 2020; Ptaszek i in. 2020): „Główna zmiana ma polegać na przejściu od edukacji skupionej na realizacji podstawy programowej do edukacji skoncentrowanej wokół ucznia i jego rozwoju, gdzie nauczyciel jest przewodnikiem prowadzącym swoich wychowanków, a nauki doświadcza się w sposób spersonalizowany" (Czapliński i in. 2020, 20). Taki model - według autorów cytowanego raportu - wymaga od nauczycieli umiejętności budowania więzi wykraczających poza wyobrażenie o relacji mistrz-uczeń oraz „łączenie poznawania, emocji i działania, wraz z ujawniającymi się w nich postawami i wartościami, buduje wartości istotne dla podniesienia skuteczności nauczania" (Czapliński i in. 2020, 21). Nauczyciel jest wówczas przewodnikiem pozostawiającym uczniom autonomię, nie podaje wiedzy, lecz organizuje proces poznawczy. Proces ten to akt komunikacji dydaktycznej (Chrząstowska 1979, 77), w którym ważnym składnikiem są relacje między uczniem i nauczycielem, wzajemna uważność i zaufanie. W takich okolicznościach jest miejsce na samodzielną postawę odbiorczą ucznia.

\section{Bibliografia:}

Biedrzycki Krzysztof i in., 2015, Dydaktyka literatury i języka polskiego w gimnazjum $w$ świetle nowej podstawy programowej, Warszawa.

Bordzoł Piotr, Zasacka Zofia, 2014, Nauczyciele języka polskiego, w: Fedorowicz M., Choińska-Mika J., Walczak D., Liczq się nauczyciele. Raport o stanie edukacji 2013, Warszawa, s. 161-185.

Brophy John E., 2012, Motywowanie uczniów do nauki, Warszawa.

Błaszczyk Katarzyna, 2019, Zmagania $z$ kanonem lektur szkolnych okiem ósmoklasisty i jego nauczyciela, w: Janus-Sitarz A. (red.), Szumial M. (współpraca), Lektury w ręku nauczyciela. Perspektywa polska i zagraniczna, Kraków, s. 237-250.

Buchner Anna, Wierzbicka Maria, 2020, Edukacja zdalna w czasie pandemii cz. II, Raport Centrum Cyfrowe Listopad 2020 https://centrumcyfrowe.pl/spoled/edukacja-zdalna-w-czasie-pandemii-2-edycja/(dostęp 27.05.2021).

https://centrumcyfrowe.pl/wp-content/uploads/sites/16/2020/11/Raport Edukacja-zdalna-w-czasie-pandemii.-Edycja-II.pdf

Chrząstowska Bożena, 1979, Teoria literatury w szkole. Z badań nad recepcja liryki, Wrocław.

Chrząstowska Bożena, 1977, Polonistyka szkolna w procesie komunikacji literackiej, „Pamiętnik Literacki” 68/3, s. 113-146.

Czapliński Przemysław i in, 2020, RAPORT EDUKACJA. Między pandemiq COVID-19 a edukacja przyszłości, Kraków.

\section{https://oees.pl/wp-content/uploads/2020/08/Raport-edukacja.pdf (dostęp} 27.05.2021).

Dudzikowa Maria (red.), 1996, Nauczyciel - uczeń. Między przemoca a dialogiem: obszary napięć i typy interakcji, Kraków. 
Filipiak Ewa, 2008, Uczenie się $w$ klasie szkolnej $w$ perspektywie socjokulturowej, w: Filipiak E. (red.), Rozwijanie zdolności uczenia się: wybrane konteksty i problemy, Bydgoszcz, s. 17-34.

Gąsiorek Przemysław, Zamorska Beata, 2019, Nauczyciel i uczeń w obliczu zagrożenia zombifikacją. Problem motywu i motywacji $w$ perspektywie kulturowo-historycznej, „Edukacja”, 2(149), s. 112-128.

Huget Patrycja, Guzik Agnieszka, 2014, Dylematy współczesnego nauczyciela, w: Biedrzycki K., Bobiński W., Janus-Sitarz A., Przybylska R. (red.) Polonistyka dziś - kształcenie jutra, Tom 1, Kraków, s. 465-476.

Jankowiak Barbara, Jaskólska Sylwia, 2020, Dobrostan nauczycieli i nauczycielek a ich postawy wobec kształcenia na odległość w czasie pandemii COVID-19, „Przegląd Pedagogiczny”, nr 1, s. 219-232.

Janus-Sitarz Anna, 2015, „Czytanie nie gryzie, ale...” Postawy gimnazjalistów wobec literatury, „Edukacja”, 1(132), s. 97-116.

Jędryszek-Geisler Aleksandra, Izdebski Paweł, 2019, Straty i zyski zasobów osobistych a wypalenie zawodowe na przykładzie badań nauczycieli „Edukacja”, 1(148), s. 20-39.

Kania Agnieszka, Mucha-Iwaniczko Klaudia, Szumal Marianna, 2020, Nauczanie zdalne w czasie pandemii. Wyzwania i doświadczenia edukacji polonistycznej, Kraków.

Kirenko Janusz, Zubrzycka-Maciąg Teresa, 2014, Współczesny nauczyciel: studium wypalenia zawodowego, Lublin.

Kocór Maria, 2019, Wypalenie zawodowe nauczycieli. Diagnoza, wsparcie, profilaktyka, Kraków.

Kulesza Marek, Kulesza Marta, 2015, Klimat szkoły jako kategoria opisowa środowiska szkolnego, „Pedagogika Społeczna”, nr 3(57), s. 113-125.

Kwiatkowski Stefan T., Walczak Dominika (red.), 2017, Kompetencje interpersonalne $w$ pracy współczesnego nauczyciela, Warszawa.

Maslach Christina, Leiter Michael P., 2008, Early predictors of job burnout and engagement, "Journal of Applied Psychology”, nr 3, s. 498-512.

Maslach Christina, Leiter Michael P., 2011, Prawda o wypaleniu zawodowym: co robić ze stresem $w$ organizacji, Warszawa.

Plebańska Marlena, Szyller Aleksandra, Sieńczewska Małgorzata, 2020, Raport - Edukacja zdalna w czasach COVID-19, 2020, Podsumowanie wyników badania Wydziału Pedagogicznego Uniwersytetu Warszawskiego, Warszawa.

https://kometa.edu.pl/uploads/publication/941/24a2_A_a nauczanie zdalne oczami nauczycieli i uczniow RAPORT.pdf?v2.8 (dostęp11.06.2021).

Ptaszek Grzegorz, Stunża Grzegorz D., Pyżalski Jacek, Dębski Maciej, Bigaj Magdalena, 2020, Edukacja zdalna: co stało się z uczniami, ich rodzicami i nauczycielami?, Gdańsk, https://zdalnenauczanie.org/wp-content/ uploads/2020/10/edukacja-zdalna.pdf(dostęp 11.06.2021).

Pyżalski Jacek, Poleszak Wiesław, 2020, Relacje przede wszystkim - nawet jeśli obecnie jedynie zapośredniczone, w: Pyżalski J. (red.), Edukacja w czasach 
pandemii wirusa COVID-19. Z dystansem o tym, co robimy obecnie jako nauczyciele, Warszawa.

Zasacka Zofia, 2019, Lektury $w$ wieku adolescencji - wybory i oczekiwania czytelnicze nastolatków, w: Janus-Sitarz A. (red.), Szumial M. (współpraca), Lektury w ręku nauczyciela. Perspektywa polska i zagraniczna, Kraków, s. $15-41$.

Zasacka Zofia, 2020, Czytelnictwo młodziė̇y szkolnej 2017, „Rocznik Biblioteki Narodowej”, nr 51, s. 11-242.

Zasacka Zofia, 2021, Spontaniczny kanon lekturowy na lekcji języka polskiego?, w: Gis A., Koc K., Kwiatkowska-Ratajczak M., Wobalis M. (red.), Narracje tożsamościowe $w$ edukacji polonistycznej. Edukacja humanistyczna - dawne problemy i nowe, Tom I, Poznań, s. 465-485.

\section{O Autorce:}

Zofia Zasacka, adiunkt w Instytucie Książki i Czytelnictwa Biblioteki Narodowej oraz Instytucie Badań Edukacyjnych. Zajmuje się socjologią literatury i socjologią młodzieży i edukacji, socjologią dzieciństwa, prowadzi badania praktyk i postaw czytelniczych w różnych środowiskach społecznych, szczególnie wśród dzieci i młodzieży. Wybrane publikacje: Książki i literatura $w$ przedszkolach - poczatki socjalizacji do czytania „Rocznik Biblioteki Narodowej" 2021, nr 52; Czytelnictwo młodzieży szkolnej 2017, „Rocznik Biblioteki Narodowej” 2020, nr 51, s. 11-242; Playing and Reading Together The Beginnings of Literary Socialization w: Deszcz-Tryhubczak, J. (Ed.), Kalla, I. B. (Ed.); Rulers of Literary Playgrounds. Routledge New York 2021; My Friend Eeyore or to Be Like Coraline - Training in Reading Engagement", "Filoteknos" 2020, Vol. 10, s. 59-68; Zaangażowanie w czytanie a osiagnięcia szkolne gimnazjalistów, „Edukacja” 2015, nr 4(135), s. 107-129 (współautor Krzysztof Bulkowski); Reading Satisfaction: Implications of Research on Adolescents' Reading Habits and Attitudes. „Polish Libraries” 2016, vol. 4, p. 40-64; Czytelnictwo dzieci i młodzieży, Warszawa 2014. 
